\title{
Interest in Sexually Transmitted Infections: Analysis of Web Search Data Terms in Eleven Large German Cities from 2015 to 2019
}

\author{
Anna Caroline Pilz*, Linda Tizek (D), Melvin Rüth, Peter Seiringer $\mathbb{D}^{\mathrm{D}}$, Tilo Biedermann and Alexander Zink \\ Department of Dermatology and Allergy, School of Medicine, Technical University of Munich, \\ 80802 Munich, Germany; linda.tizek@tum.de (L.T.); melvin.rueth@gmx.de (M.R.); peter.seiringer@tum.de (P.S.); \\ tilo.biedermann@tum.de (T.B.); alexander.zink@tum.de (A.Z.) \\ * Correspondence: annacaroline.pilz@mri.tum.de; Tel.: +49-89-4140-3176
}

check for updates

Citation: Pilz, A.C.; Tizek, L.; Rüth, M.; Seiringer, P.; Biedermann, T.; Zink, A. Interest in Sexually Transmitted Infections: Analysis of Web Search Data Terms in Eleven Large German Cities from 2015 to 2019. Int. J. Environ. Res. Public Health 2021, 18 , 2771. https://doi.org/10.3390/ ijerph18052771

Academic Editor:

Jennifer M. Grossman

Received: 24 December 2020

Accepted: 4 March 2021

Published: 9 March 2021

Publisher's Note: MDPI stays neutral with regard to jurisdictional claims in published maps and institutional affiliations.

Copyright: (c) 2021 by the authors. Licensee MDPI, Basel, Switzerland. This article is an open access article distributed under the terms and conditions of the Creative Commons Attribution (CC BY) license (https:// creativecommons.org/licenses/by/ $4.0 /)$.

\begin{abstract}
Incidence of sexually transmitted infections (STIs) such as chlamydia, gonorrhea, and syphilis has increased in recent years in the US and in European countries. In order to implement effective educational programs, the interests of target populations have to be identified. Since the internet is an important source of information-gathering on health issues, this study investigates web search data in large German cities related to STIs. Google Ads Keyword Planner was used to identify STI-related terms and their search volume in eleven German cities from June 2015 to May 2019. The data obtained were analyzed descriptively with regard to total search volumes, search volumes of specific thematic areas, and search volumes per 100,000 inhabitants. Overall, 741 terms with a total search volume of 5,142,560 queries were identified, with more than $70 \%$ of all search queries including a specific disease and "chlamydia" being the overall most often searched term $(n=1,196,160)$. Time courses of search behavior displayed a continuous interest in STIs with synchronal and national rather than regional peaks. Volumes of search queries lacked periodic patterns. Based on the findings of this study, a more open public discussion about STIs with linkage to increased media coverage and clarification of responsibilities among all STI-treating disciplines concerning management of STIs seem advisable.
\end{abstract}

Keywords: sexually transmitted diseases; STI; web search data; large german cities

\section{Introduction}

Worldwide, more than one million sexually transmitted infections (STIs) occur every day, resulting in approximately 376 million new infections with chlamydia, gonorrhea, syphilis, and trichomoniasis per year [1,2]. Additionally, rising incidences of chlamydia, gonorrhea, and syphilis in the United States (US) and in European countries are present [3-5]. In the US, between 2014 and 2018, gonorrhea infections in men increased by over $75 \%$ and chlamydia infections by about 38\% [3]. In Germany, national data are only available for human immunodeficiency virus (HIV) infections and syphilis. While the incidence of HIV has decreased in the last decade [6], the incidence of syphilis increased by $83 \%$ to 9.1 cases /100,000 inhabitants between 2010 and 2017 [7]. In addition to the direct health risks for the affected individual, including imminent and long-term risk such as infertility, STIs present a high socioeconomic burden for healthcare systems. For example, in the United Kingdom, costs for STIs, without the treatment of HIV, were estimated to be GBP 620 million in 2011 [8].

To target STIs effectively, different control strategies are applied worldwide, such as increased screenings combined with partner notifications and simplified therapies in order to reduce the time of infectiousness. Furthermore, sexual health education is intensified [9]. Limited knowledge about STIs in adolescents and underestimation of risks for obtaining STIs in adults emphasize the need for improvement of sexual health education 
programs $[10,11]$. One problem regarding STIs is that they are still considered a taboo topic. The perception of STIs is strongly influenced by myths and metaphors, rendering affected persons susceptible to stigmatization and discrimination [12]. Discussions or extraction of information concerning taboo topics such as conversations about suicide or sexually related topics are often transferred to the internet $[13,14]$. Analyses of web search behavior revealed that the category of sexually related queries is among the most common search categories on the internet $[15,16]$ and that the web is a main source for sexual health information for young people [17].

Health education programs inform target populations and often aim at inducing behavioral changes [18]. In order to be effective, they need to match the interests of their target populations $[19,20]$. Interviews and surveys are a well-established way to investigate the interest of smaller and specific target populations [21,22]. However, web search data provides information about interests in an almost completely non-selective way. In Germany, about $90 \%$ of the population uses the internet [23], with Google being by far $(95 \%)$ the leading search engine [24]. Up to now, analyses of STI-related web search data focused on correlations of searches for distinct diseases and their infection rates in the context of STI surveillance $[25,26]$. But search data terms were not yet analyzed in depth and thus it was not yet identified what people want to know about STIs.

In order to improve sexual health education programs, this study investigates German inhabitants' interest in STIs and analyzes whether there were regional and periodic differences in search interest and frequency in eleven German cities.

\section{Materials and Methods}

\subsection{Study Design}

A retrospective longitudinal study displaying the web search volume of terms related to STIs in eleven large German cities between June 2015 and May 2019 was conducted. The selected cities were Berlin, Hamburg, Munich, Cologne, Frankfurt, Stuttgart, Dusseldorf, Dortmund, Leipzig, Hannover, and Nuremberg, which are all among the fifteen biggest cities in Germany and are representative of all German regions (Figure 1). By using the Google Ads Keyword Planner, the average monthly search volume of relevant keywords/key terms in German for the term "venereal diseases" was identified. "Venereal diseases" ("Geschlechtskrankheiten") constitutes the most common German term for STIs. Google Ads Keyword Planner is usually used to optimize placements of advertisements but can also be successfully employed for scientific purposes $[27,28]$. The search volume indicates the total number of searches for the respective keywords. In this study, search volume was restricted to users whose preferred language was German, and to the area of the selected eleven cities. No institutional review board approval and informed consent was necessary for this study since the data were publicly available. 


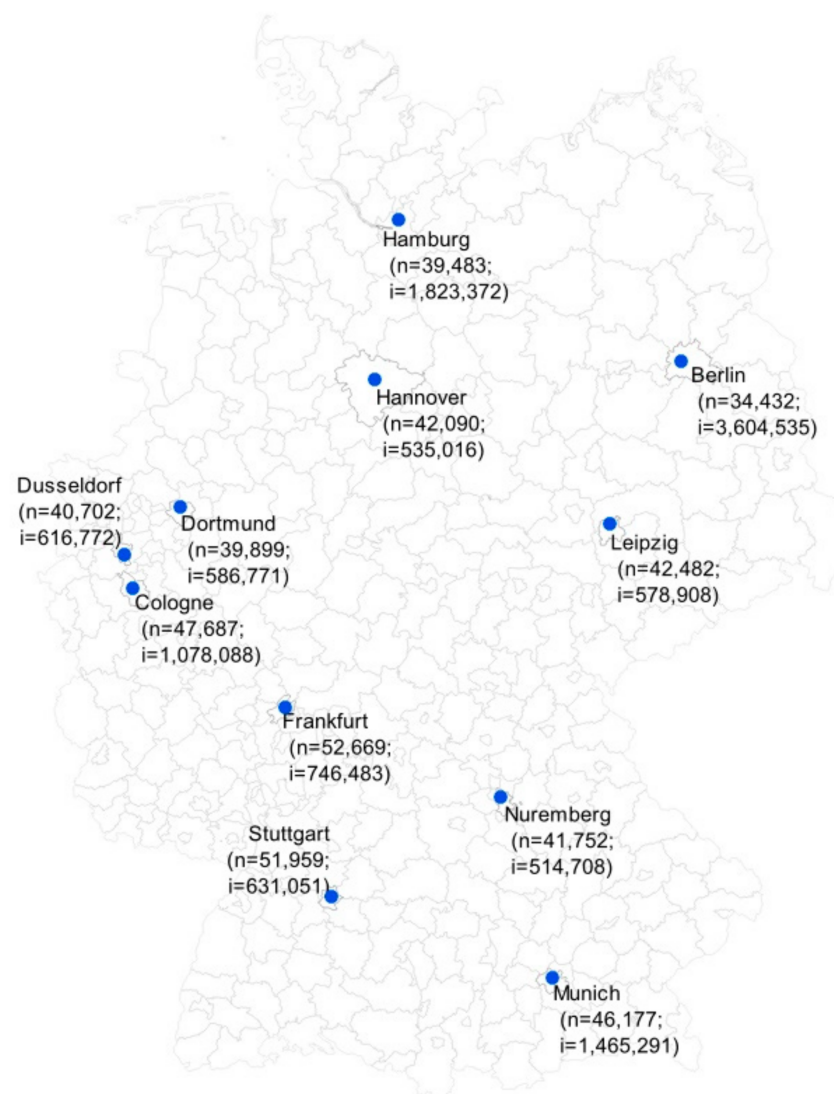

Figure 1. Map showing the regional distribution of the selected eleven German cities ( $n$ : overall search volume per 100,000 inhabitants; i: number of inhabitants).

\subsection{Categorization}

All identified search terms were reviewed, and keywords that did not refer to the initial search term, "venereal diseases" (e.g., disinfection, bacterial diseases list, transmittable diseases), were excluded from further analysis. The remaining keywords were assigned to the following seven categories: "Specific diseases" (e.g., gonorrhea), "gender" (e.g., venereal disease vagina), "symptoms" (e.g., clap symptoms woman), "diagnostics" (e.g., sexually transmitted diseases test), "treatment" (e.g., venereal diseases which physician), "transmission" (e.g., chlamydia infection without intercourse), and "general" (e.g., venereal diseases list). Within the category "gender", keywords containing male references (e.g., male venereal diseases or venereal diseases penis) and female references (e.g., female venereal diseases or venereal diseases vagina) were differentiated. Keywords that fit into multiple categories were assigned to all of them.

\subsection{Statistical Analysis}

Descriptive data were generated for the identified and categorized keywords. To compare the search volume within the cities, the search volume was calculated in relation to the average number of inhabitants between the years 2015 and 2019 and displayed as number of searches per 100,000 inhabitants [29,30]. To adjust for the proportion of foreigners, who would probably not Google in the German language, data on the average proportion of foreigners between the year 2015 and 2018 were collected [31]. Then, the corresponding number of foreigners in each city was calculated and subtracted from the number of all inhabitants in the respective city. The search volume adjusted to the proportion of foreigners was displayed as the number of searches per 100,000 inhabitants. One-way analysis of variance (ANOVA) was applied to detect differences in search volume per 100,000 inhabitants across the selected cities. 


\section{Results}

\subsection{Overview}

A total of 741 keywords associated with the German term for "venereal diseases" were identified. Of these, 29 keywords unrelated to STIs were excluded from further analyses. The remaining 712 keywords with a total search volume of 5,044,250 queries were assigned to seven categories (Figure 2). The highest proportion of search volume referred to the category "specific disease" (73.06\%; 232 keywords), followed by "symptoms" (11.19\%; 159 keywords) and "general" (10.74\%, 126 keywords), whereas only $2.38 \%$ (52 keywords) of the search volume was related to "treatment". Overall, the most frequently searched terms were "chlamydia" $(n=1,196,160)$, "genital warts" $(n=559,690)$, "HIV" $(n=458,850)$, "clap" $(n=376,170)$, and "venereal diseases" $(n=268,310)$ (Supplementary Table S1).

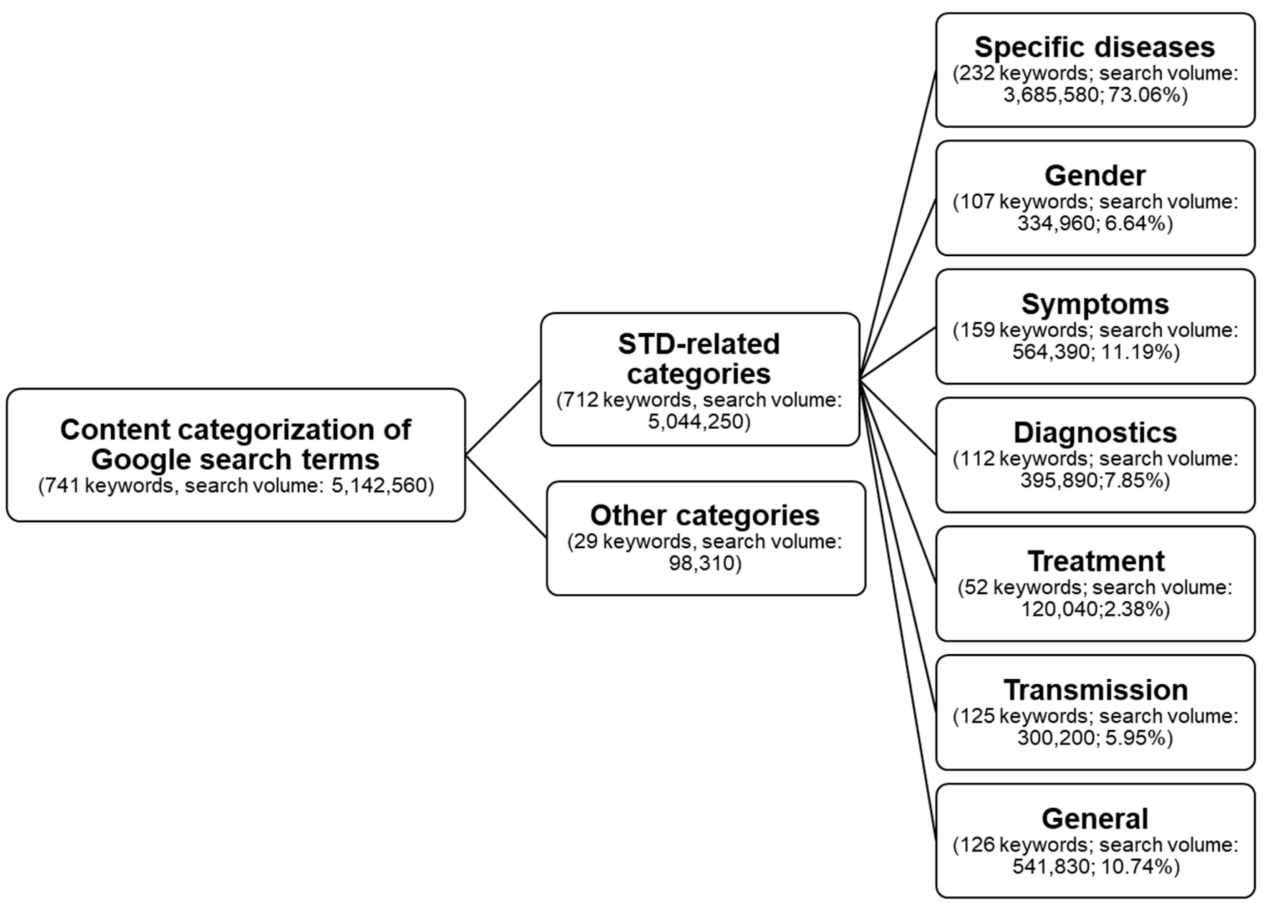

Figure 2. Content categorization of search terms.

\subsection{Comparison of Cities}

The highest absolute search volume was found in the three largest German cities, Berlin $(n=1,241,130)$, Hamburg $(n=719,920)$, and Munich $(n=676,630)$, while the lowest number of searches was found in Nuremberg $(n=214,900)$. However, when calculating the search volume per 100,000 inhabitants, Frankfurt and Stuttgart had the highest search volumes, with 52,669 and 51,959 queries per 100,000 inhabitants, respectively (Figure 1 and Table 1). This was also the case after the adjustment for the proportion of foreigners in all cities (Frankfurt: 73,834 queries /100,000 inhabitants; Stuttgart; 68,684 queries/100,000 inhabitants). Nevertheless, the differences in the total search volumes per 100,000 inhabitants across cities were not significant. 


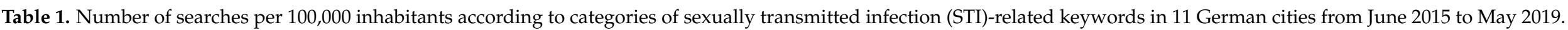

\begin{tabular}{|c|c|c|c|c|c|c|c|c|c|}
\hline \multirow[b]{2}{*}{ City } & \multirow{2}{*}{$\begin{array}{c}\text { Avg. Number of Inhabitants } \\
\text { 2015-2019, (Overall Search } \\
\text { Volume) }^{1}\end{array}$} & \multirow{2}{*}{$\begin{array}{l}\text { Avg. Proportion of Foreigners } \\
\text { 2015-2018 }{ }^{2}(\%),(\text { Adjusted } \\
\text { Overall Search Volume) }^{1}\end{array}$} & \multicolumn{7}{|c|}{ Categories and Number of Searches/100,000 Inhabitants, $n(\%)^{3}$} \\
\hline & & & $\begin{array}{l}\text { Specific Diseases } \\
\quad(\mathbf{k}=\mathbf{2 3 2})^{4}\end{array}$ & $\begin{array}{c}\text { Gender } \\
(\mathrm{k}=107)\end{array}$ & $\begin{array}{c}\text { Symptoms } \\
(\mathbf{k}=159)\end{array}$ & $\begin{array}{l}\text { Diagnostics } \\
(\mathrm{k}=112)\end{array}$ & $\begin{array}{c}\text { Treatment } \\
(\mathrm{k}=52)\end{array}$ & $\begin{array}{l}\text { Transmission } \\
\quad(\mathbf{k}=\mathbf{1 2 5})\end{array}$ & $\begin{array}{r}\text { General } \\
(\mathrm{k}=126)\end{array}$ \\
\hline \multirow[t]{2}{*}{ Berlin } & $3,604,535$ & 17.08 & 26,626 & 1969 & 3620 & 2393 & 691 & 1559 & 3505 \\
\hline & $(n=34,432)$ & $(n=41,522)$ & $(77.33)$ & $(5.72)$ & $(10.51)$ & $(6.95)$ & $(2.01)$ & $(4.53)$ & $(10.18)$ \\
\hline \multirow[t]{2}{*}{ Hamburg } & $1,823,372$ & 15.73 & 29,324 & 2437 & 4330 & 3056 & 846 & 2057 & 4162 \\
\hline & $(n=39,483)$ & $(n=46,850)$ & $(74.27)$ & (6.17) & $(10.97)$ & $(7.74)$ & $(2.14)$ & $(5.21)$ & (10.54) \\
\hline \multirow[t]{2}{*}{ Munich } & $1,465,291$ & 25.65 & 34,178 & 2809 & 4939 & 3754 & 1005 & 2537 & 4840 \\
\hline & $(n=46,177)$ & $(n=62,108)$ & $(74.02)$ & $(6.08)$ & $(10.70)$ & (8.13) & $(2.18)$ & $(5.49)$ & (10.48) \\
\hline \multirow[t]{2}{*}{ Cologne } & $1,078,088$ & 19 & 34,891 & 3258 & 5538 & 3631 & 1170 & 2947 & 5010 \\
\hline & $(n=47,687)$ & $(n=58,873)$ & (73.17) & (6.83) & $(11.61)$ & $(7.61)$ & $(2.45)$ & $(6.18)$ & $(10.51)$ \\
\hline \multirow[t]{2}{*}{ Frankfurt } & 746,483 & 28.63 & 37,351 & 3629 & 6090 & 4442 & 1373 & 3555 & 5850 \\
\hline & $(n=52,669)$ & $(n=73,834)$ & $(70.88)$ & $(6.89)$ & (11.56) & $(8.43)$ & $(2.61)$ & $(6.75)$ & $(11.10)$ \\
\hline \multirow[t]{2}{*}{ Stuttgart } & 631,051 & 24.36 & 36,157 & 3786 & 6126 & 4534 & 1342 & 3689 & 5832 \\
\hline & $(n=51,959)$ & $(n=68,684)$ & $(69.59)$ & (7.29) & (11.79) & (8.73) & $(2.58)$ & $(7.10)$ & $(11.22)$ \\
\hline Dusseldorf & $(n=40,702)$ & $(n=50,530)$ & $(69.72)$ & (7.40) & $(11.72)$ & (8.47) & $(2.85)$ & $(7.21)$ & (11.15) \\
\hline \multirow[t]{2}{*}{ Dortmund } & 586,771 & 16.65 & 27,372 & 3279 & 4799 & 3047 & 1111 & 2930 & 4705 \\
\hline & $(n=39,899)$ & $(n=47,870)$ & $(68.60)$ & (8.22) & (12.03) & $(7.64)$ & $(2.78)$ & (7.34) & (11.79) \\
\hline \multirow[t]{2}{*}{ Leipzig } & 578,908 & 8.53 & 29,626 & 3408 & 5032 & 3493 & 1168 & 3244 & 4901 \\
\hline & $(n=42,482)$ & $(n=46,441)$ & $(69.74)$ & $(8.02)$ & $(11.84)$ & $(8.22)$ & $(2.75)$ & $(7.64)$ & $(11.54)$ \\
\hline \multirow[t]{2}{*}{ Hannover } & 535,016 & 21.48 & 29,306 & 3196 & 4807 & 3602 & 1256 & 3034 & 4594 \\
\hline & $(n=42,090)$ & $(n=50,513)$ & (69.63) & (7.59) & $(11.42)$ & $(8.56)$ & $(2.98)$ & $(7.21)$ & $(10.92)$ \\
\hline \multirow[t]{2}{*}{ Nuremberg } & 514,708 & 16.68 & 27,831 & 3425 & 5119 & 3757 & 1259 & 3388 & 4985 \\
\hline & $(n=41,752)$ & $(n=53,170)$ & $(66.66)$ & $(8.20)$ & (12.26) & $(9.00)$ & $(3.02)$ & $(8.12)$ & $(11.94)$ \\
\hline \multirow[t]{2}{*}{ All cities } & $12,180,995$ & 19.02 & 30,257 & 2750 & 4633 & 3250 & 985 & 2465 & 4448 \\
\hline & $(n=41,411)$ & $(n=51,138)$ & (73.06) & $(6.64)$ & (11.19) & $(7.85)$ & (2.38) & $(5.95)$ & (10.74) \\
\hline
\end{tabular}

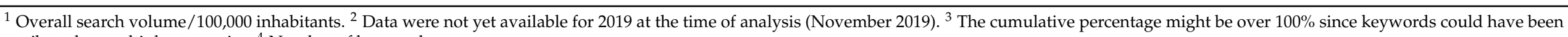
attributed to multiple categories. ${ }^{4}$ Number of keywords. 


\subsection{Most Searched Keywords in Categories}

The category "specific diseases" had by far the highest search volume with $3,685,580$ queries (30,257 queries $/ 100,000$ inhabitants). In this category, the five most common keywords were "chlamydia" (9820 queries/100,000 inhabitants; 32.46\%), "genital warts" (4595 queries/100,000 inhabitants; 15.19\%), "HIV" (3767 queries/100,000 inhabitants; 12.45\%), "clap" (3088 queries/100,000 inhabitants; 10.21\%), and "gonorrhea" (1559 queries /100,000 inhabitants; $5.15 \%$ ). Since clap is the colloquial term for gonorrhea, these two keywords together represent $15.36 \%$ of the category "specific diseases". In the category "symptoms", the five most common keywords include either "chlamydia" or "clap". Furthermore, the word "symptoms" itself was predominant as opposed to naming specific symptoms such as "discharge". In the category "treatment", four out of the top five keywords contain the word "physician" $(21.74 \%)$, but none included "chlamydia" (Table 2). The search volume of keywords including male references $(n=70$, search volume: 209,940 queries) was 1.7 times higher than the search volume of keywords including female references ( $n=35$, search volume: 125,020 queries). Neither the search volume of keywords with female references nor the search volume of keywords with male references per 100,000 inhabitants differed significantly between cities.

Table 2. The five most-searched-for terms within each category across all examined cities expressed as search queries per 100,000 inhabitants.

\begin{tabular}{|c|c|}
\hline Category and Search Terms & $n^{1}(\%)$ \\
\hline \multicolumn{2}{|l|}{ Specific diseases $(n=30,257)$} \\
\hline Chlamydia & $9820(32.46)$ \\
\hline Genital warts & 4595 (15.19) \\
\hline HIV & $3767(12.45)$ \\
\hline Clap & $3088(10.21)$ \\
\hline Gonorrhea & $1559(5.15)$ \\
\hline \multicolumn{2}{|l|}{ Gender $(n=2750)$} \\
\hline Chlamydia symptoms woman & $294(10.69)$ \\
\hline burning urethra man venereal disease & $199(7.22)$ \\
\hline incubation period chlamydia man & $165(6.00)$ \\
\hline bacterial infection genital area man & $131(4.75)$ \\
\hline venereal disease vagina & $128(4.66)$ \\
\hline \multicolumn{2}{|l|}{ Symptoms $(n=4633)$} \\
\hline Chlamydia symptoms & 909 (19.62) \\
\hline Clap symptoms & $403(8.70)$ \\
\hline Chlamydia symptoms woman & $294(6.34)$ \\
\hline Chlamydia symptoms man & $199(4.29)$ \\
\hline Clap symptoms woman & $131(2.82)$ \\
\hline \multicolumn{2}{|l|}{ Diagnostics $(n=3250)$} \\
\hline Chlamydia test & $808(24.85)$ \\
\hline Venereal diseases test & $382(11.75)$ \\
\hline Test venereal diseases & $111(3.41)$ \\
\hline Test for venereal diseases & $62(1.90)$ \\
\hline Sexually transmitted diseases test & $53(1.64)$ \\
\hline
\end{tabular}


Table 2. Cont.

\begin{tabular}{cc}
\hline Category and Search Terms & $\boldsymbol{n}^{\mathbf{1}(\mathbf{\%})}$ \\
\hline Treatment $(\boldsymbol{n}=\mathbf{9 8 5})$ & $101(10.20)$ \\
\hline Clap treatment & $71(7.25)$ \\
\hline Physician for venereal diseases & $52(5.25)$ \\
\hline Physician venereal diseases & $51(5.17)$ \\
\hline Venereal diseases physician & $40(4.07)$ \\
\hline Venereal diseases which physician & $195(7.91)$ \\
\hline Transmission ( $\boldsymbol{n}=\mathbf{2 4 6 4 )}$ & $64(2.59)$ \\
\hline Chlamydia transmission & $63(2.54)$ \\
\hline Venereal diseases oral & $62(2.51)$ \\
\hline Clap incubation period & $55(2.25)$ \\
\hline Clap transmission & \\
\hline Chlamydia infection without intercourse & $2203(49.52)$ \\
\hline General ( $\boldsymbol{n}=\mathbf{4 4 4 8 )}$ & $209(4.7)$ \\
\hline Venereal diseases & $65(1.45)$ \\
\hline Sexually transmitted diseases & $60(1.35)$ \\
\hline Venereal diseases pictures & $56(1.25)$ \\
\hline Skin and venereal diseases & \\
\hline Venereal diseases list & \\
\hline
\end{tabular}

${ }^{1}$ Number of searches/100,000 inhabitants.

\subsection{Time Course of Search Queries}

Considering all cities, the average monthly number of searches was 9554, resulting in 863 queries per 100,000 inhabitants. The highest number of searches was in October 2015 ( $n=131,660 ; 1081$ searches /100,000 inhabitants) and the lowest in August 2016 ( $n=88,480$; 726 searches $/ 100,000$ inhabitants). The biggest range in number of searches within one city was found in Dusseldorf with 1678 searches per 100,000 inhabitants in June 2015 compared to 694 searches per 100,000 inhabitants in April 2016 and August 2018, displaying a range of 984 .

During the whole study period, no seasonal variations were detected, but a somewhat parallel search behavior between the cities was recognized. Eight cities had the highest or second highest number of searches in October 2015. The other cities were Cologne (July 2017; 1242 searches/100,000 inhabitants), Frankfurt (November 2017; 1302 searches /100,000 inhabitants), Dusseldorf (June 2015; 1678 searches /100,000 inhabitants), and Leipzig (January 2019; 1083 searches/100,000 inhabitants). Another common peak was identified in November 2017.

In addition, the time course of search terms related to chlamydia, gonorrhea/clap, and HIV was investigated. Regarding all keywords containing "chlamydia", two main peaks were observed in October 2015 and November 2017. Keywords with "gonorrhea/clap" showed especially high peaks in July 2017, in March 2018, and in October 2018, and keywords containing "HIV” peaked in November 2015 and February 2016 (Figure 3). 

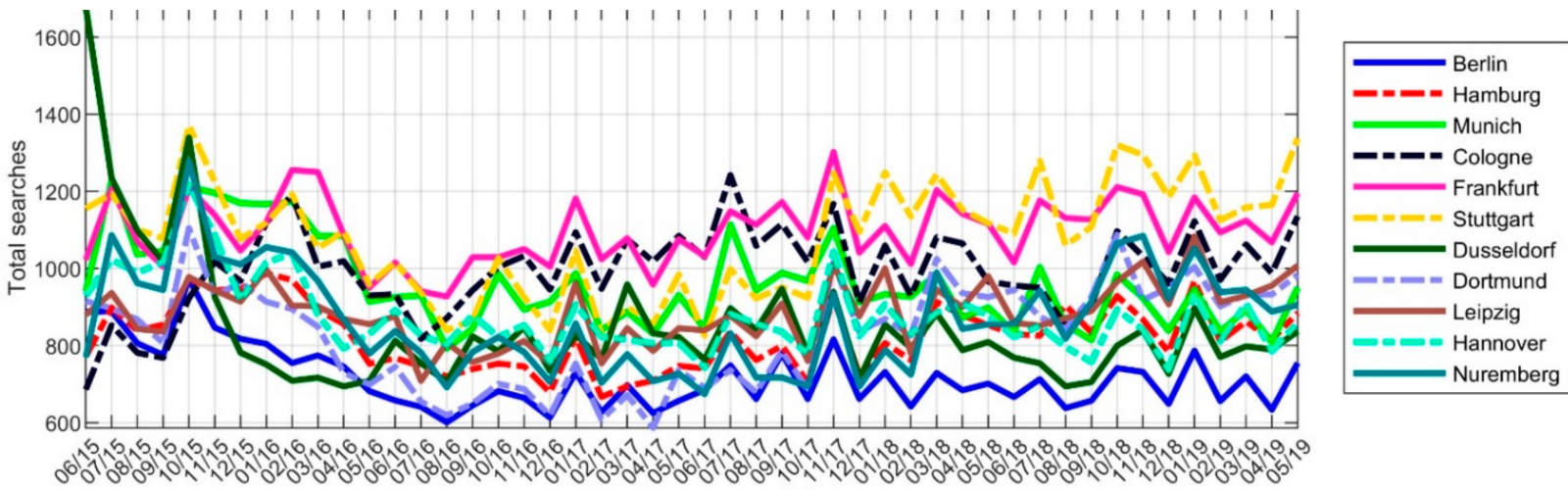

(a)
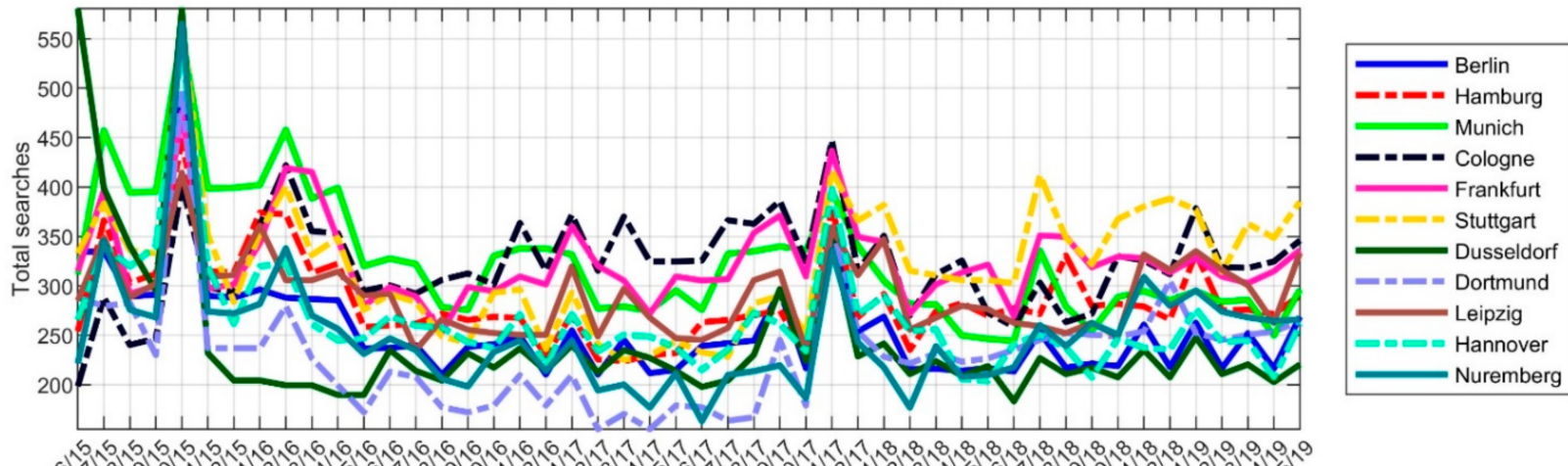

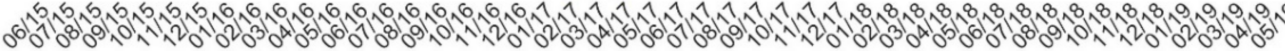

(b)
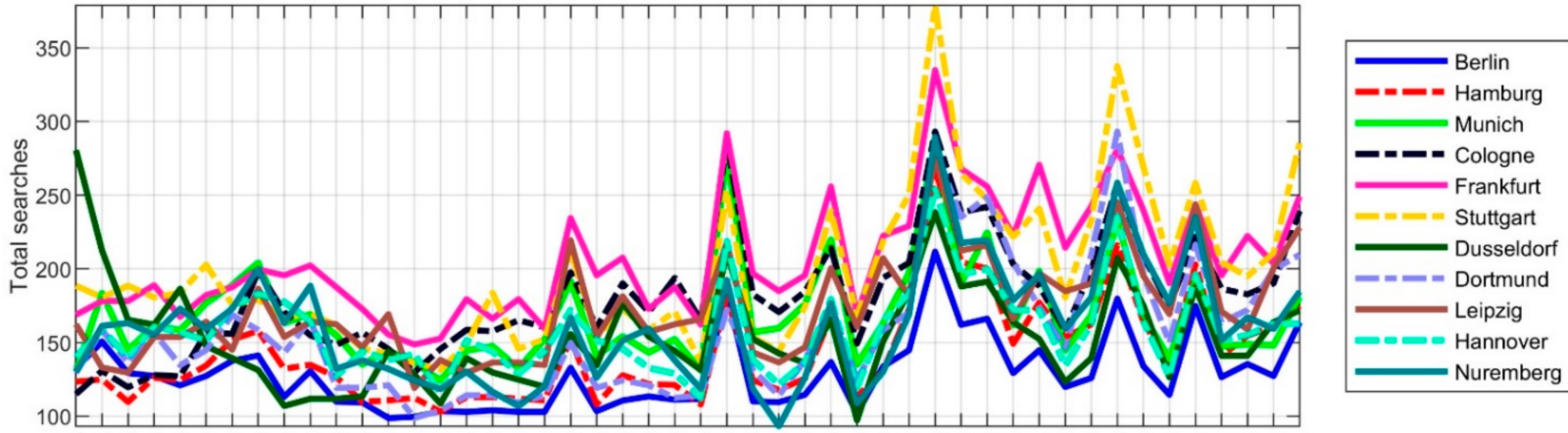

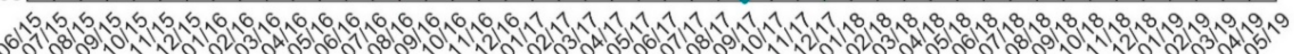

(c)
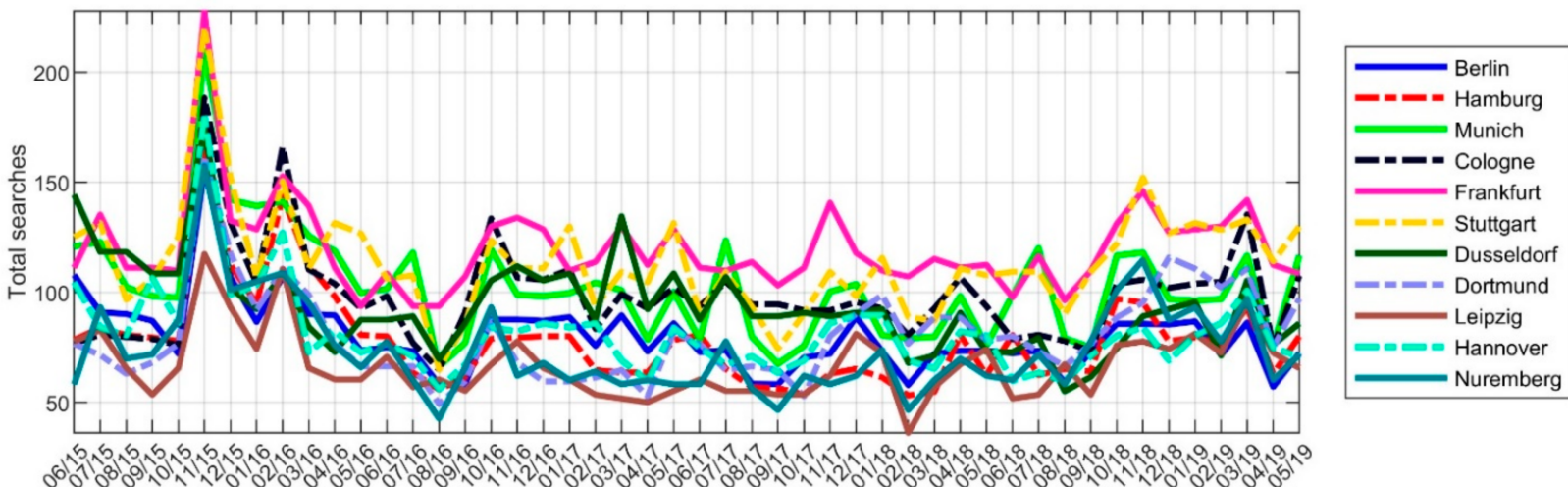

(d)

Figure 3. Trends in Google search volumes from June 2015 to May 2019 per 100,000 inhabitants. Sum of all search terms (a) related to STIs, (b) containing "chlamydia", (c) containing "gonorrhea/clap", and (d) containing "HIV". 


\section{Discussion}

The aim of the presented study was to assess STI-related web search data to examine people's interest and to assess whether there were regional or periodic differences across German cities. It was found that the vast majority of searches focused on specific diseases such as chlamydia and gonorrhea. No considerable differences between the cities regarding search interest and time course were observed.

During the analyzed time period of four years, a total of 5,142,560 queries were identified in the eleven large German cities examined, indicating 41,411 queries per 100,000 inhabitants. A trend toward fewer searches per 100,000 inhabitants in larger cities compared to smaller cities was seen. This observation remained after adjustment to the proportion of foreigners in the analyzed cities and has already been described in the context of other Google data analyses [32,33]. Overall, the number of searches per 100,000 inhabitants related to STIs was nearly twice as high than that of "pruritus" ( $n=21,701$ searches $/ 100,000$ inhabitants) and also higher than that of "skin cancer" ( $n=35,573$ searches/100,000 inhabitants) [32,33], representing highly prevalent disease conditions. Chronic pruritus affects approximately $14 \%$ of the general population in Germany at any time, and skin cancer represents the most common malignancy in Germany [34,35]. With regard to skin cancer, one possible explanation might be the age difference. Skin cancer mainly appears in the elderly, who use the internet less often [23]. A second reason for the higher number of searches regarding STIs, which show lower estimated prevalences than pruritus and skin cancer, might be that STIs are stigmatized and to some extent still taboo $[12,36]$. Therefore, STIs can be regarded as a highly relevant online search topic. As a consequence, public health institutions should try to discuss STIs more openly. One possibility would be to offer interactive seminars in schools which combine knowledge transfer and reduction of insecurities about STIs.

Analyzing the categories and their most frequent keywords, it immediately becomes apparent that more than $70 \%$ of all searches included a specific disease, especially chlamydia. Chlamydia represents the most common bacterial STI in Germany [37]. Additionally, annual screening is offered to women under 25 years and every pregnant woman, and every woman undergoing an abortion is tested for chlamydia [38]. Therefore, many women will hear about chlamydia for the first time in the setting of a screening and may look it up online afterwards. The described factors might be reasons "chlamydia" is the most Googled STI in Germany. Moreover, the search term "chlamydia" was present in the top 5 search terms of all categories except for "treatment" and "general", though in the latter, it was excluded by default. In Germany, women with suspected STIs are usually treated by gynecologists, especially with regard to chlamydia. However, for men or people at high risk who require regular screenings for all STIs, it is often not evident which physician is the primary contact person. Dermatologists, urologists, and general practitioners share the medical care of these patients [39]. It seems that there is a great need to further clarify responsibilities among medical disciplines especially for the treatment of men since the category "treatment" contains search terms including "physician" and "clap" rather than "chlamydia" and since the number of search terms including "men" was 1.7 times more frequent than those including "women". Hence, a public health measure could be the creation of official web sites that list detailed information about the availability and the range of services of all public health and medical institutions involved in the care of STIs.

A relatively consistent monthly search volume was seen during the whole study period except for a few peaks. Nevertheless, the majority of cities had their largest search volume in October 2015, which was mainly caused by an increase of searches for chlamydiarelated keywords, and which indicates a national rather than regional trend. In contrast to studies that investigated pruritus, skin cancer, or borreliosis, no seasonal variations were detected $[28,32,33]$, which suggests that interest in STIs is independent of periodic external factors such as climate. The few observed national peaks in search volume may be due to increased media coverage, as seen in other studies [40,41]. A recent study showed that Google Trend data in relation to COVID-19 were rather associated with media coverage than epidemiologic data [42]. In the presented study, for example, a high increase in the 
national search volume for "gonorrhea" was observed in July 2017 when the World Health Organization warned against antibiotic resistances to gonorrhea [43] and in March 2018, when the first case of this multiresistant germ was published in Britain [44]. Both incidents were intensively featured in the main German newspapers and television news [45-47]. Some peaks might be due to the coverage in popular German television series, which are watched by approximately 650,000 to 800,000 people every day, as in October 2018 or November 2017, when a protagonist got infected with gonorrhea [48] or chlamydia, respectively. [49]. Concerning HIV, peaks in search volume were seen in November 2015 and February 2016. In November 2015, Charlie Sheen, an actor of world renown, revealed his HIV infection on NBC's Today show, and in February 2016, German scientists reported a breakthrough toward curing HIV [50,51]. Therefore, with regard to the optimization of educational programs, the timing of campaigns should be carefully chosen. For example, information on STIs could appear in commercial breaks of episodes of TV series in which STIs are addressed.

In general, the internet is frequently used as a source for health-related information $[16,52]$, and search engine data have been successfully used in prior studies to describe population interests and behavior with regard to public health topics $[27,28,53,54]$. The advantage is the great amount of data, which can be easily and anonymously acquired from millions of people. By analyzing the search terms, it is possible to get an overview of people's interest and thereby reveal unmet needs that are not seen in everyday practice. This is especially true for topics which are experienced as shameful, such as STIs. In contrast to the alternative of, e.g., (online) questionnaires, analyses of search engine data display hypothesis-free approaches. Additionally, there are no wordings, formats or contexts of questions that can influence the population studied, and participation biases are eliminated $[55,56]$. Conversely, search term data do not include any demographic information, which renders it hard to identify interests of subgroups. Furthermore, the presented data might not be fully representative of the general population as internet users tend to be younger [57]. Moreover, in this study, only data from users whose preferred language was German and who lived in the area of the selected eleven cities were analyzed. Therefore, no statement about rural areas and non-German speaking communities was possible. However, STIs affect primarily younger people, which may attenuate the effect of this limitation $[5,58]$. Another limitation is that Google presents an automatic completion of search terms, which could influence people's search queries. Google Ads Keyword planner also only displays estimated, not exact, search volumes, and related keywords/key terms are automatically provided by an unknown algorithm. Since no general reporting requirement for chlamydia and/or gonorrhea exists in Germany, no nationwide epidemiological data are available for these diseases. Although this would be very helpful for public health matters in general, it appears unlikely that positive correlations to disease incidences could have been made in this study. The observed uniform national monthly trends shown are at least partly explained by enhanced public attention following increased media coverage of news or storylines in television series. Furthermore, with regard to chlamydia, the most often searched-for keyword, testing is often done in screening scenarios, which are independent of the time of infection.

\section{Conclusions}

In summary, the study results showed a relatively high search volume related to STIs in German cities, with search queries focusing on specific diseases, especially chlamydia and gonorrhea. Furthermore, instead of regional peaks, national trends with no seasonal correlations were seen. The knowledge gained may be helpful for the planning of big educational campaigns as well as future awareness and prevention strategies. It may be advisable to intensify efforts to discuss STIs more publicly, to clarify responsibilities among STI-treating disciplines especially for management of men with STIs, and to link educational programs directly to broadcast news when public attention is already present. 
Supplementary Materials: The following are available online at https:/ /www.mdpi.com/1660-460 1/18/5/2771/s1, Table S1: The five most-searched-for terms across all examined cities expressed as search queries per 100,000 inhabitants.

Author Contributions: Conceptualization, A.C.P., L.T., and A.Z.; methodology, A.C.P., L.T., and M.R.; software, L.T., M.R., and P.S.; validation, A.C.P. and T.B.; formal analysis, A.C.P., P.S., and T.B.; investigation, all; resources, M.R.; data curation, M.R. and P.S.; writing—original draft preparation, A.C.P., L.T., and A.Z.; writing-review and editing, all; visualization, all; supervision, A.Z.; project administration, T.B. and A.Z.; funding acquisition, T.B. and A.Z. All authors have read and agreed to the published version of the manuscript.

Funding: This research received no external funding.

Data Availability Statement: The data can be obtained from the Corresponding Author upon request.

Conflicts of Interest: The authors declare no conflict of interest.

\section{References}

1. Rowley, J.; Vander Hoorn, S.; Korenromp, E.; Low, N.; Unemo, M.; Abu-Raddad, L.J.; Chico, R.M.; Smolak, A.; Newman, L.; Gottlieb, S.; et al. Chlamydia, gonorrhoea, trichomoniasis and syphilis: Global prevalence and incidence estimates, 2016. Bull. World Health Organ. 2019, 97, 548-562. [CrossRef] [PubMed]

2. World Health Organization. Report on Global Sexually Transmitted Infection Surveillance, 2018; World Health Organization: Geneva, Switzerland, 2018. Available online: https:/ / www.who.int/reproductivehealth/publications/stis-surveillance-2018/en/ (accessed on 7 November 2020).

3. U.S. Department of Health and Human Services; Centers for Disease Control and Prevention. Sexually Transmitted Disease Surveillance 2018. 2019. Available online: https:/ / www.cdc.gov/std/stats18/natoverview.htm (accessed on 7 November 2020).

4. European Centre for Disease Prevention and Control (ECDC). Syphilis_Annual Epidemiological Report for 2018; European Centre for Disease Prevention and Control (ECDC): Stockholm, Sweden, 2020. Available online: https://www.ecdc.europa.eu/en/ publications-data/syphilis-annual-epidemiological-report-2018 (accessed on 7 November 2020).

5. European Centre for Disease Prevention and Control (ECDC). Gonorrhoea-Annual Epidemiological Report for 2018; European Centre for Disease Prevention and Control (ECDC): Stockholm, Sweden, 2020. Available online: https://www.ecdc.europa.eu/ en/publications-data/gonorrhoea-annual-epidemiological-report-2018 (accessed on 7 November 2020).

6. Robert Koch Institut. Epidermiologisches Bulletin, Schätzung der Zahl der HIV-Neuinfektionen und der Gesamtzahl von Menschen, die mit HIV in Deutschland leben Stand Ende 2018. 2019. Available online: https:/ /www.rki.de/DE/Content/Infekt/ EpidBull/Archiv/2019/Ausgaben/46_19.pdf?_blob=publicationFile (accessed on 7 November 2020).

7. Buder, S.; Schöfer, H.; Meyer, T.; Bremer, V.; Kohl, P.K.; Skaletz-Rorowski, A.; Brockmeyer, N. Bacterial sexually transmitted infections. J. Dtsch. Dermatol. Ges. 2019, 17, 287-315. [CrossRef] [PubMed]

8. Government Digital Service. Public Health England. Guidance. Health Matters: Preventing STIs. 2019. Available online: https: / / www.gov.uk/government/publications/health-matters-preventing-stis/health-matters-preventing-stis (accessed on 7 November 2020).

9. Catchpole, M. Sexually transmitted infections: Control strategies. BMJ 2001, 322, 1135-1136. [CrossRef] [PubMed]

10. Von Rosen, F.T.; Von Rosen, A.J.; Müller-Riemenschneider, F.; Damberg, I.; Tinnemann, P. STI Knowledge in Berlin Adolescents. Int. J. Environ. Res. Public Health 2018, 15, 110. [CrossRef]

11. Clifton, S.; Mercer, C.H.; Sonnenberg, P.; Tanton, C.; Field, N.; Gravningen, K.; Hughes, G.; Mapp, F.; Johnson, A.M. STI Risk Perception in the British Population and How It Relates to Sexual Behaviour and STI Healthcare Use: Findings from a Cross-sectional Survey (Natsal-3). EClinicalMedicine 2018, 2-3, 29-36. [CrossRef] [PubMed]

12. Badura-Lotter, G. Sexually transmitted diseases: The impact of stigma and taboo on current medical care. Urologe A 2014, 53, 548-556. [CrossRef]

13. Westerlund, M. Talking suicide: Online conversations about a taboo subject. Nordicom Rev. 2013, 34, 35-46. [CrossRef]

14. Albright, J.M. Sex in America online: An exploration of sex, marital status, and sexual identity in internet sex seeking and its impacts. J. Sex Res. 2008, 45, 175-186. [CrossRef] [PubMed]

15. Jansen, J.; Spink, A.; Saracevic, T. Real Users and Real Needs: A Study and Analysis of User Queries on the Web. Inf. Process. Manag. 2000, 36, 207-227. [CrossRef]

16. Spink, A.; Koricich, A.; Jansen, B.J.; Cole, C. Sexual information seeking on web search engines. Cyberpsychol. Behav. 2004, 7, 65-72. [CrossRef]

17. Buhi, E.R.; Daley, E.M.; Fuhrmann, H.J.; Smith, S.A. An Observational Study of How Young People Search for Online Sexual Health Information. J. Am. Coll. Health 2009, 58, 101-111. [CrossRef]

18. Israel, B.A.; Cummings, K.M.; Dignan, M.B.; Heaney, C.A.; Perales, D.P.; Simons-Morton, B.G.; Zimmerman, M.A. Evaluation of Health Education Programs: Current Assessment and Future Directions. Health Educ. Q. 1995, 22, 364-389. [CrossRef] 
19. Kreuter, M.W.; Lukwago, S.N.; Bucholtz, R.D.; Clark, E.M.; Sanders-Thompson, V. Achieving cultural appropriateness in health promotion programs: Targeted and tailored approaches. Health Educ. Behav. 2003, 30, 133-146. [CrossRef]

20. Ayala, G.X.; Elder, J.P. Qualitative methods to ensure acceptability of behavioral and social interventions to the target population. J. Public Health Dent. 2011, 71 (Suppl. 1), S69-S79. [CrossRef]

21. Bazzi, A.R.; Biancarelli, D.L.; Childs, E.; Drainoni, M.-L.; Edeza, A.; Salhaney, P.; Mimiaga, M.J.; Biello, K.B. Limited Knowledge and Mixed Interest in Pre-Exposure Prophylaxis for HIV Prevention Among People Who Inject Drugs. AIDS Patient Care STDS 2018, 32, 529-537. [CrossRef]

22. McCarthy, O.; Carswell, K.; Murray, E.; Free, C.; Stevenson, F.; Bailey, J.V. What Young People Want from a Sexual Health Website: Design and Development of Sexunzipped. J. Med. Internet Res. 2012, 14, e127. [CrossRef]

23. Statistisches Bundesamt. Income, Consumption and Living Conditions. Internet Use by Individuals and Age Groups in \%. 2020. Available online: https://www.destatis.de/EN/Themes/Society-Environment/Income-Consumption-Living-Conditions / _graphics/_Interactive/it-use-age.html (accessed on 7 November 2020).

24. Statistica. Market Share of the Leading Search Engines in Germany in 2018. 2020. Available online: https://www.statista.com/ statistics /445002/market-shares-leading-search-engines-germany/ (accessed on 7 November 2020).

25. Johnson, A.K.; Bhaumik, R.; Tabidze, I.; Mehta, S.D. Nowcasting Sexually Transmitted Infections in Chicago: Predictive Modeling and Evaluation Study Using Google Trends. JMIR Public Health Surveill. 2020, 6, e20588. [CrossRef] [PubMed]

26. Zhang, Q.; Chai, Y.; Li, X.; Young, S.D.; Zhou, J. Using internet search data to predict new HIV diagnoses in China: A modelling study. BMJ Open 2018, 8, e018335. [CrossRef] [PubMed]

27. Zink, A.; Schuster, B.; Rüth, M.; Pereira, M.P.; Philipp-Dormston, W.G.; Biedermann, T.; Ständer, S. Medical needs and major complaints related to pruritus in Germany: A 4-year retrospective analysis using Google AdWords Keyword Planner. J. Eur. Acad. Dermatol. Venereol. 2019, 33, 151-156. [CrossRef]

28. Scheerer, C.; Rüth, M.; Tizek, L.; Köberle, M.; Biedermann, T.; Zink, A. Googling for Ticks and Borreliosis in Germany: Nationwide Google Search Analysis From 2015 to 2018. J. Med. Internet Res. 2020, 22, e18581. [CrossRef] [PubMed]

29. Statistische Ämter des Bundes und der Länder. Statistik. Code: 12411. Inhalt: Fortschreibung des Bevölkerungsstandes. 2020. Available online: https:/ / www.regionalstatistik.de/genesis / online?language=de\&sequenz=statistikTabellen\&selectionname= 12411\#abreadcrumb (accessed on 7 November 2020).

30. Statistisches Bundesamt. Genesis-online.12411-0015: Bevölkerung: Kreise, Stichtag. 2020. Available online: https: / / www-genesis.destatis.de/genesis/online?operation=previous\&levelindex=3\&step=2\&titel=Tabellenaufbau\&levelid= 1606564217864\&levelid=1606564166560\#abreadcrumb (accessed on 7 November 2020).

31. Statistische Ämter des Bundes und der Länder. AI002-1: Regionalatlas Deutschland. Indikatoren des Themenbereichs "Bevölkerung". 2020. Available online: https://www.regionalstatistik.de/genesis/online?language=de\&sequenz= tabelleAufbau\&selectionname=AI002-1\#astructure (accessed on 7 November 2020).

32. Tizek, L.; Schielein, M.; Rüth, M.; Ständer, S.; Pereira, M.P.; Eberlein, B.; Biedermann, T.; Zink, A. Influence of Climate on Google Internet Searches for Pruritus Across 16 German Cities: Retrospective Analysis. J. Med. Internet Res. 2019, 21, e13739. [CrossRef] [PubMed]

33. Tizek, L.; Schielein, M.C.; Rüth, M.; Szeimies, R.M.; Philipp-Dormston, W.G.; Braun, S.A.; Hecker, C.; Eberlein, B.; Biedermann, T.; Zink, A. Interest in Skin Cancer in Urban Populations: A Retrospective Analysis of Google Search Terms in Nine Large German Cities. Acta Derm. Venereol. 2019, 99, 797-804. [CrossRef] [PubMed]

34. Matterne, U.; Apfelbacher, C.J.; Loerbroks, A.; Schwarzer, T.; Büttner, M.; Ofenloch, R.; Diepgen, T.L.; Weisshaar, E. Prevalence, correlates and characteristics of chronic pruritus: A population-based cross-sectional study. Acta Derm. Venereol. 2011, 91, 674-679. [CrossRef] [PubMed]

35. Augustin, J.; Kis, A.; Sorbe, C.; Schäfer, I.; Augustin, M. Epidemiology of skin cancer in the German population: Impact of socioeconomic and geographic factors. J. Eur. Acad. Dermatol. Venereol. 2018, 32, 1906-1913. [CrossRef]

36. Jacob, L.; Duse, D.A.; Kostev, K. Prevalence and treatment of sexually transmitted infections in men followed by urologists in Germany-A cross sectional study with 347,090 men. Ger. Med. Sci. 2018, 16, Doc03.

37. Deutsche STI-Gesellschaft. Gesellschaft zur Förderung der Sexuellen Gesundheit. Epidermiologie. 2020. Available online: https:/ / www.dstig.de/sexuelle-gesundheit/epidemiologie.html (accessed on 7 November 2020).

38. Arbeitsgemeinschaft der Wissenschaftlichen Medizinischen Fachgesellschaften. Infektionen mit Chlamydia trachomatis. AWMFRegister Nr. 059/005-S2k-Leitlinie. 2016. Available online: https://www.awmf.org/uploads/tx_szleitlinien/059-0051_S2k_ Chlamydia-trachomatis_Infektionen_2016-12.pdf (accessed on 7 November 2020).

39. Bundeszentrale für gesundheitliche Aufklärung. Liebesleben. STI—Zu welchem Arzt soll ich gehen?. 2020. Available online: https:/ / www.liebesleben.de/fuer-alle/sexuell-uebertragbare-infektionen/arzt-zustaendig/ (accessed on 7 November 2020).

40. Mukherjee, P.; Jansen Bernard, J. Conversing and searching: The causal relationship between social media and web search. Internet Res. 2017, 27, 1209-1226. [CrossRef]

41. Noar, S.M.; Ribisl, K.M.; Althouse, B.M.; Willoughby, J.F.; Ayers, J.W. Using Digital Surveillance to Examine the Impact of Public Figure Pancreatic Cancer Announcements on Media and Search Query Outcomes. JNCI Monogr. 2013, 2013, 188-194. [CrossRef]

42. Sousa-Pinto, B.; Anto, A.; Czarlewski, W.; Anto, J.M.; Fonseca, J.A.; Bousquet, J. Assessment of the Impact of Media Coverage on COVID-19-Related Google Trends Data: Infodemiology Study. J. Med. Internet Res. 2020, 22, e19611. [CrossRef] 
43. World Health Organization. Antibiotic-Resistant Gonorrhoea on the Rise, New Drugs Needed. 2017. Available online: https:// www.who.int/news/item/07-07-2017-antibiotic-resistant-gonorrhoea-on-the-rise-new-drugs-needed (accessed on 7 November 2020).

44. Government Digital Service. Public Health England. Research and Analysis. Multi-Drug Resistant Gonorrhoea in England: 2018. 2018. Available online: https:/ / www.gov.uk/government/publications/multi-drug-resistant-gonorrhoea-in-england-2018 (accessed on 7 November 2020).

45. MDR. Weltgesundheitsorganisation Medikamente gegen Gonorrhö wirken bald nicht mehr. 2017. Available online: https: //www.mdr.de/wissen/mensch-alltag/gonorrhoe-102.html (accessed on 7 November 2020).

46. Bild. Brite fängt sich Super-Tripper ein! Kann mir das auch passieren? 2018. Available online: https://www.bild.de/ratgeber/ gesundheit/ratgeber/tripper-antibiotikaresistenz-55243318.bild.html (accessed on 7 November 2020).

47. Welt. Brite mit Super-Tripper infiziert-Antibiotika unwirksam. 2018. Available online: https://www.welt.de/gesundheit/ article174994196/Brite-mit-Super-Tripper-infiziert-Antibiotika-unwirksam.html (accessed on 7 November 2020).

48. RTLII. Folge 1478-Wird Jule wieder laufen können? Kevin hat einen Tripper. 2021. Available online: https://www.rtl2.de/ sendungen/koeln-50667/folge/179956-staffel-7-folge-1478-kevin-hat-einen-tripper (accessed on 11 February 2021).

49. TVmovie. Nach Sex bei BTN: Krankheits-Schock! 2017. Available online: https://www.tvmovie.de/news/nach-sex-bei-btnkrankheits-schock-96687 (accessed on 7 February 2021).

50. Süddeutsche Zeitung. Charlie Sheen ist HIV-Positiv. 2015. Available online: https://www.sueddeutsche.de/panorama/usschauspieler-charlie-sheen-ist-hiv-positiv-1.2740911 (accessed on 7 November 2020).

51. Das Erste. Bristant. Forschern gelingt Durchbruch gegen AIDS. 2016. Available online: https://www.mdr.de/brisant/forscherngelingt-durchbruch-gegen-aids-100.html (accessed on 7 November 2020).

52. Beck, F.; Richard, J.B.; Nguyen-Thanh, V.; Montagni, I.; Parizot, I.; Renahy, E. Use of the internet as a health information resource among French young adults: Results from a nationally representative survey. J. Med. Internet Res. 2014, 16, e128. [CrossRef]

53. Nuti, S.V.; Wayda, B.; Ranasinghe, I.; Wang, S.; Dreyer, R.P.; Chen, S.I.; Murugiah, K. The use of google trends in health care research: A systematic review. PLoS ONE 2014, 9, e109583. [CrossRef]

54. Husnayain, A.; Fuad, A.; Lazuardi, L. Correlation between Google Trends on dengue fever and national surveillance report in Indonesia. Glob. Health Action 2019, 12, 1552652. [CrossRef] [PubMed]

55. Arafa, A.E.; Anzengruber, F.; Mostafa, A.M.; Navarini, A.A. Perspectives of online surveys in dermatology. J. Eur. Acad. Dermatol. Venereol. 2019, 33, 511-520. [CrossRef] [PubMed]

56. Schwarz, N. Self-reports: How the questions shape the answers. Am. Psychol. 1999, 54, 93-105. [CrossRef]

57. Koch, W.; Frees, B. ARD/ZDF-Onlinestudie 2017: Neun von zehn Deutschen Online. 2017. Available online: https: / www.ardzdf-onlinestudie.de/files/2017/Artikel/917_Koch_Frees.pdf (accessed on 7 November 2020).

58. European Centre for Disease Prevention and Control. Chlamydia Infection-Annual Epidemiological Report for 2017. 2019. Available online: https:/ / www.ecdc.europa.eu/en/publications-data/chlamydia-infection-annual-epidemiological-report-2017 (accessed on 7 November 2020). 